Article

\title{
Technocratic Populism in Hybrid Regimes: Georgia on My Mind and in My Pocket
}

\author{
David Aprasidze ${ }^{1, *}$ and David S. Siroky ${ }^{2,3}$ \\ ${ }^{1}$ School of Arts and Sciences, Ilia State University, 0162 Tbilisi, Georgia; E-Mail: david_aprasidze@iliauni.edu.ge \\ ${ }^{2}$ School of Politics and Global Studies, Arizona State University, Tempe, AZ 85287, USA; E-Mail: david.siroky@asu.edu \\ ${ }^{3}$ Institute of Sociology, Czech Academy of Science, 11000 Prague, Czech Republic \\ * Corresponding author
}

Submitted: 16 June 2020 | Accepted: 24 September 2020 | Published: 17 December 2020

\begin{abstract}
Most studies of technocratic populism have focused on democracies under stress (e.g., Italy, Czech Republic). This article builds on and extends these studies by analyzing a hybrid regime-post-Soviet Georgia-and argues that technocratic populism in this context is utilized as a façade to cover authoritarian and oligarchic tendencies, while suspending (or reversing) democratization efforts. The state apparatus is weaponized against current and potential political opponents. Ideology is irrelevant, loyalty is key, and passivity is encouraged. The government aims to chip away at institutional checks and balances, and to demobilize the public by undermining confidence in the country's representative institutions while increasing dependence on experienced personalities, the 'can do experts.' The result is most often a stable partial-reform equilibrium. We illustrate this argument with evidence from Georgia, where Bidzina Ivanishvili, the richest man in the country, came to power in 2012 and, despite not holding any official position in the government since 2013, has run the state as a firm.
\end{abstract}

\section{Keywords}

Georgia; hybrid regimes; Ivanishvili; populism; technocratic populism

\section{Issue}

This article is part of the issue "Varieties of Technocratic Populism around the World" edited by Petra Guasti (Institute of Sociology of the Czech Academy of Sciences, Czech Republic) and Lenka Buštíková (Institute of Sociology of the Czech Academy of Sciences, Czech Republic / Arizona State University, USA).

(C) 2020 by the authors; licensee Cogitatio (Lisbon, Portugal). This article is licensed under a Creative Commons Attribution 4.0 International License (CC BY).

\section{Introduction}

Managing 'the state as a firm,' and using expertise to bypass accountability, is now emerging as a respectable method of governance that has become known as 'technocratic populism' (Buštíková \& Guasti, 2019). While the rise of modern populism has been extensively studied in the scholarly literature (Caiani \& Graziano, 2019; Canovan, 1999; Grzymala-Busse, 2019; Mudde, 2004; Mudde \& Kaltwasser, 2012; Pappas, 2019; Stanley, 2008; Weyland, 2020), and there are now several studies of technocracy (Bickerton \& Accetti, 2017; Caramani, 2017; De la Torre, 2013), technocratic populism is still relatively underexplored (see Guasti \& Buštíková, 2020). Building on this emerging literature, we understand technocracy and populism as two alternatives challenging representative, party-based democracy (Caramani, 2017). Yet, at least in some ways, technocracy and populism contradict each other, for populism views direct link with voters as a source of its legitimacy, whereas technocracy is premised on the rule of experts (Bartha, Boda, \& Szikra, 2020). However, when technocracy merges with populism, both change in a dialectical fashion: The populist element rests on the capabilities of the leader to connect with voters beyond the established institutional channels of representation; the technocratic element legitimizes the leadership in its quest to resolve issues of governance by relying on the outsider expertise (e.g., business savvy).

Technocratic populists do not necessarily pit the elite vs. the 'people,' especially when in power, but instead 
carve out a category of the 'ordinary people' (Buštíková \& Babos, 2020; Buštíková \& Guasti, 2019). As an outputoriented governance strategy, technocratic populism supplants the traditional right-left political landscape by appealing to the people with all-purpose expertise garnered outside politics (Guasti, 2020). Despite its potentially broad applicability, technocratic populism as a framework has mostly been applied to analyzing democracies under stress in Western Europe (Silvio Berlusconi in Italy), Eastern Europe (Andrej Babiš in the Czech Republic) and Latin America (Rafael Correa in Ecuador). There is a need to extend this focus, first and foremost we suggest, to analyzing governance in hybrid regimes, and secondarily beyond Europe (its EU part) and Latin America.

This article aims to do both; specifically, this study asks: How and under what circumstances does technocratic populism emerge in hybrid regimes? What are its principal characteristics, and what strategies do technocratic populists use to stay in power and govern? Drawing on evidence from Georgia-a hybrid regime that, since 2012, has witnessed the gradual emergence of technocratic populism-we address these questions and show that hybrid regimes offer fertile soil for technocratic populism to take root because party systems are under-institutionalized, the nature of governance is elitist (March, 2017) and its quality is poor. We conclude that technocratic populism represents a new and non-trivial obstacle for democratic transitions that needs to be incorporated into debates on democratization.

First, we describe the emergence of technocratic populism and identify its main features in Georgia. This focuses on how Ivanishvili entered politics and succeeded in defeating political opponents, and then on how he constructed a new government using an 'ideology-free' business model in which he is the CEO and his main task is to select good managers. Next, we examine the specific management strategies that have characterized technocratic populist rule in Georgia. This emphasizes the specific methods that technocratic populists tend to use in an effort to undermine representative institutions, to contain opposition and to manage crises with ideologyfree balancing and the leader's direct personal involvement. The final section summarizes the analysis and discusses its implications for democratization.

\section{Technocratic Populism in a Hybrid Regime}

I think the experience and characteristics that I gained as a result of my long business activities...will help me to correctly pursue my activities in politics. (Ivanishvili, 2011b)

This study examines the logic of technocratic populism in a hybrid regime, and focuses on Georgia-a country with a political system that has been variously characterized as 'feckless pluralism' and 'dominant power politics' (Berglund, 2014). In 2011, Bidzina Ivanishvili-the richest
Georgian (Ivanishvili's fortune amounted to US $\$ 5,3$ billion in 2013, corresponding to almost half of Georgia's GDP; Bloomberg, 2020; Gente, 2013)-created a new party, the Georgian Dream, which one year later won the parliamentary elections by a landslide. Thus began the era of technocratic populism in Georgia.

In this section, we illustrate how Ivanishvili established his image as a respectable businessman and at a crucial juncture successfully invested it into Georgian politics. Then, we describe the key characteristics of the governance model he has implemented since 2012.

\subsection{Winning in Business, Investing in Politics}

Ivanishvili's was born in a small village in western Georgia. From a working-class family, he later moved to the capital and graduated with distinction from Tbilisi State University, then to Moscow where he received his PhD (Kandidat nauk, or Candidate of Sciences) from the Moscow Institute of Labor and Social Issues in 1986 (Stevenson, 2010). Ivanishvili soon abandoned the scientific path and turned to business, a largely unknown profession before Gorbachev's Perestroika. He founded a cooperative-the only private company allowed in the Soviet Union of the 1980s, followed by other firms and then a bank (Gente, 2013). While there is much we still do not know about this period of his life, we do know that post-Soviet oligarchs were usually not shy about using all available means-including corruption and criminal networks - to survive and thrive in the new era of capitalism in 'the wild East' (Braguinsky, 2009; Guriev \& Rachinsky, 2005). In his rare interviews, Ivanishvili acknowledged that in order to protect himself and his businesses, he collaborated with Russian law enforcement agencies, in particular with Moscow's Regional Office for Combating Organized Crime of the Ministry of Interior. Ivanishvili even partially funded the office, which not only defended his business from criminals but also helped to 'persuade' hesitant debtors to pay their loans back on time and substituted for paying the mafia for protection and extortion ("The most mysterious," 2005).

Ivanishvili returned from Russia and settled back in Georgia in 2004, following the Rose Revolution of 2003-a peaceful upheaval that brought a new generation of politicians into power under the leadership of Mikheil Saakashvili (Siroky \& Aprasidze, 2011; Wheatley, 2005). Saakashvili's government-initiated reforms propelled Georgia's rapid modernization. Ivanishvili initially supported Saakashvili in his reforms, especially during the first years when he was providing financial assistance to Georgian law enforcement agencies (Buckley, 2012). Otherwise, Ivanishvili remained behind the scenes like the mysterious Maecenas, funding theaters and museums, and bringing the intelligentsia-famous writers, actors and athletes-onto his payroll. He did not criticize the Saakashvili government, even during the 2007 crisis, when the Georgian government responded to growing political opposition with the violent dispersal 
of rallies and the closing down of TV channels sympathetic to the opposition. He also remained silent in 2008 during the short Russian-Georgian war (Lanskoy \& Areshidze, 2008).

In October 2011, however, the mysterious billionaire suddenly issued his first public statement, and announced his decision to create a new political party, saying he would run for parliamentary elections, scheduled exactly one year later, for October 2012. Ivanishvili underlined his reasons - that the authoritarian rule of Saakashvili left him disappointed and that he decided to enter politics to prevent the regime from manipulating the constitution and elections (Ivanishvili, 2011a). He stated:

Many people ask and many people are surprised, why I, a successful businessman and an absolutely prosperous person, risked everything and decided to go into politics? The answer to this question is very simple-because I see that I am losing my homeland, and when you are losing your homeland, nothing has any price-neither your property nor money, nor any privileged status. (Ivansihvili, 2011b)

This strong personal appeal came as Georgia had arrived at a critical juncture-Saakashvili's two terms in power had expired and he was banned by the constitution from the next presidential elections in 2013. A year before Ivanishvili's appeal, Saakashvili's partythe United National Movement (UNM)-had initiated constitutional revisions that would have moved Georgia from a semi-presidential to a parliamentary model. This caused speculations about Saakashvili's plans to become the next prime minister (Walker, 2011), and fueled animosity towards Saakashvili's semi-authoritarian rule and harsh methods, which alienated not only other political parties but also most of the population. UNM controlled all branches of the central government, regional as well as local administrations, and marginalized all non-UNM actors. The separation between the party and the state had become increasingly blurred. Media and most of the opposition were silenced. The security services used surveillance and blackmail to harass and intimidate opponents. The appropriation of private property for dubious reasons became common practice (Hammarberg, 2013).

The fragmented opposition, with no access to necessary resources or media, was not in a position to challenge UNM in the 2012 elections. Ivanishvili changed this when he created a new party-the Georgian Dreamand forged an alliance with major oppositional parties. Ivanishvili's financial resources and media access leveled the playing field. He reopened TV Channel 9, which had been defunct since 2004, and thereby provided the opposition with a nationwide platform. With the help of this coalition, Ivanishvili achieved a remarkable victory in very tense and contested parliamentary elections.

As the new prime minister, he portrayed himself as 'the nation's savior' (Atilgan \& Aprasidze, 2013). His can- didate, Giorgi Margvelashvili, easily won the presidential elections one year later, which completed the first peaceful transfer of power ever in Georgia. Almost immediately, however, Ivanishvili resigned and left his formal position in politics. He announced that his task-removing the authoritarian regime of Saakashvili and installing a democratic regime-had been fulfilled. He promised to be an active citizen and support and check the government as a member of civil society. He noted:

I am quitting politics, but I remain an active citizen.... promise that for at least next twenty years I will put my energy, knowledge and experience in the service of getting my homeland on its feet. I will support any government, which will serve the people. I will not get tired by reminding those who are in power that the government should serve the people and not vice versa, that we need laws to secure more freedom and not for imposing more restrictions. (Ivanishvili, 2013)

Ivanishvili never actually ceded control over his party and never truly departed from power, however. Today, he is still the most influential figure in the country and became the party chairman again in 2018. After almost eight years in power, many issues with which Ivanishvili was discontent during the Saakashvili era-political interference in business, the media and the judiciary-still remain serious problems. Moreover, as we argue in the next sections, Ivanishvili created a new obstacle in Georgian politics-technocratic populism-that has largely stalled Georgia's democratic transition and resulted in what has been called 'a partial reform equilibrium' (Hellman, 1998).

\subsection{Georgia: A Joint Stock Company}

Ivanishvili has utilized his power to run Georgia as a firm-or, more precisely, as a joint stock company. If the CEO selects qualified managers (to fulfill the role of politicians)-Ivanishvili has repeatedly argued-the country will run smoothly like his firms. "The fact that businesses I have launched in Russia are working absolutely properly, although I have not been in Russia already for nine years, is enough proof speaking in favor of my managerial skills" (Ivanishvili, 2011b). The important trait for Ivanishvili's managers is not only competence or experience but also loyalty, which has generated a faux technocracy. Indeed, the key figures in the government are his closest followers, often former employees of his companies. Out of four prime ministers who headed the government of Georgia after him, three of them were previously managers in his companies. The current Minister of Interior (previously head of State Security Agency) and the Head of Special State Protection Service (protection of high-ranking officials) are his former personal bodyguards. The most recent Prosecutor General was his family lawyer. The current and previous Ministers of Health previously managed 
the hospital which Ivanishvili has been funding in his home municipality. Though the list is not exhaustive, it reveals that Ivanishvili runs the country like a joint stock company, where he is the Chair of the Board (and only shareholder); and the ministers and public officials are his executive officers, who can be appointed, moved, removed and reappointed at any time the chair decides based on their performance.

Ivanishvili is surrounded by an 'inner circle,' comprised mainly of former employees in his businesses that serve in key power positions. The 'outer circle' is composed of actors that are indirectly linked to the center, usually through actors in the inner circle. For instance, the parliament and ruling party are run by immediate associates of Ivanishvili, who enjoy the direct links with him, while 'the Marsh' (using an analogy to the majority in the National Convention during the French revolution of late 18th century) consists mostly of businessmen who seem more interested in securing their business interests than in the public service. Law enforcement agencies, especially the security services and prosecutor's office, are important verticals that channel information to the chair and send signals down the system. The state security agency is involved in conducting 'loyalty checks' for potential managers (in the outer circle) to determine if they can be trusted. At the same time, Ivanishvili has his own 'parallel intelligence' through a group of trusted individuals who deliver the vox populi to the leader. These individuals do not occupy any formal positions but have frequent contact with the Chair. Even in the case of closed and directly subordinated power centers (the inner circle), Ivanishvili has installed parallel mechanisms that serve as a check on them (comparable with the strategy described by Migdal, 1989). In fact, the political weight of public figures is not necessarily bound to their official positions but is based on whether or not they have direct access to the Chair. Although Ivanishvili does not seem to be directly involved with the outer circle or in every-day operative management, his existence nonetheless limits managerial creativity, especially in the outer circle, since managers wait for signals, fearing possible negative reactions, and therefore do not invest in creative solutions or take initiative without prior approval.

The result is a distortion of accountability mechanisms-high ranking officials (executive officers) feel responsible towards Ivanishvili (the company chair/the owner) rather than to public institutions with oversight functions or to the public. In short, the technocratic populist leader in a hybrid context can easily exploit and capture key institutions at the expense of its capacities and legitimacy, since politicians are managers bound to the polity through the Chair. This adaptive clientelistic network that has captured the state and its institutions is the real backbone of the technocratic populist system of governance in a hybrid context and generates a serious impediment to further democratization, reform and innovation.

\subsection{Ideology is Dead! Long Live Trust!}

Technocratic populism is distinguished in part by its absence of political ideology, its unmediated relation with voters and its emphasis on expert knowledge as a source of legitimacy. It 'just gets things done,' and emphasizes trust in the leader (Guasti, 2020). The six party coalition forged by Ivanishvili in 2011-2012 was an ideological mixture of rather incompatible political voices, including left-centrist (Georgian Dream itself), liberals (Republicans, Free Democrats), centerrights (Industrialist), and nationalists (Conservative Party, National Forum) as well as few individuals representing pre-Rose Revolution era political and business groups, who saw the opportunity to return to the political scene (Atilgan \& Aprasidze, 2013). Since 2016, Georgian Dream has been ruling alone, without coalition partners, but still remains an amalgam of dissimilar ideologies. Officially, Georgian Dream presents itself as a center-left party (Georgian Dream, 2020). However, this ideological angle was selected more to distinguish itself from its main adversary-the center-right UNM-since indeed, the policies of the Georgian Dream government have been all over the ideological map and not at all consistent over time (see also Section 3.3).

It is true that political parties, especially ruling ones, often lack clear ideological profiles in the post-Soviet space (Hale, 2010), and more frequently represent mechanisms of top-down political mobilization and control, centered around a single leader or a small group (Bader, 2009). It is also true that all parties in Georgia, including the UNM, have exploited populist rhetoric and policies over time, but some parties, and UNM in particular, have advanced a clear vision for modernizing the country. Georgian Dream and Ivanishvili have never tried to advance any overarching vision for Georgia's development, either domestically or in foreign policy. Instead of ideology, strategy or vision, Ivanishvili's message to the public is to trust him personally because of his managerial skills and expertise in business.

In a 2018 interview, Ivanishvili indicated that he intends to continue to play a role in the country's future for at least another decade, asking the voters to stick with him and the government of his choosing until at least 2030, when he expects Georgia to have finally reached the promised land. Georgia will at that point be past the point of no return, Ivanishvili said, with the country's gross domestic product per capita having almost tripled to $\$ 10,000$ or-fingers crossed-even $\$ 12,000$, and the Georgian dream of joining the European Union already a reality (Lomsadze, 2018).

\section{Technocratic Populism in Three Steps: A MBA's Guide to Running a Country}

Although there is often no grand vision that unites technocratic populists, it is possible to identify several management strategies or 'best practices' that character- 
ize their governance, including delegitimizing democratic institutions, weakening parties, containing opposition, balancing with ideology-free populist moves, and the leader directly addressing the masses in order to demobilize public distress or protests. We address each of these in turn, and illustrate each with examples from Georgia.

\subsection{Delegitimizing Democratic Institutions}

At the institutional level, technocratic populism-as we see with Ivanishvili-is particularly concerned about the autonomy of representative and intermediary institutions. It seeks to undermine public trust in them. Ivanishvili's efforts have thus far mainly focused on the presidency, the parliament and political parties. Indeed, public opinion polls show declining public trust in the key institutions, such as the presidency and parliament, since 2012 (see Figures 1 and 2).

Ivanishvili's efforts to undermine the power of the presidency began by promoting candidates who were neither popular nor had political experience. In the 2013 presidential elections, Ivanishvili personally, without consulting with his colleagues, nominated Giorgi Margvelashvili. A philosopher by background, Margvelashvili was appointed Minister of Education in the new government. But he lacked political experience and political party support. Many had expected Irakli Alasania-a popular politician and leader of the coalition member party Free Democrats, defense minister and Deputy prime minister in the government of Ivanishvilito be nominated ("PM Ivanishvili," 2012). In next 2018 elections, Ivanishvili backed an independent candidate, Salome Zurabishvili. The daughter of Georgian emigrants, born and raised in France, she was a political unknown, without political or public support. Zurabishvili won elections only thanks to Ivanishvili's efforts ("Highlights," 2019). However, her public approval ratings remain among the lowest in the country. Whereas only 16 percent of people thought the president was doing a 'bad job' in 2015, 54 percent thought so by end of 2019 (see Figure 1).

Public confidence in the parliament as an institution dropped in tandem. Whereas only 14 percent of people thought the parliament was doing a 'bad job' in 2012, a staggering 57 percent thought so by 2019 (see Figure 2). During 2012-2016, Ivanishvili's Georgian Dream representation in the parliament included several representatives from other parties and the parliament was relatively more active. In the 2016 elections, Georgian Dream managed to secure a supermajority without coalitional partners. However, the party's popularity has since declined, and many of its prominent members have left its ranks. The party still retains an absolute majority in the parliament, mainly thanks to the so-called businessman-MPs in the 'outer circle' (i.e. businessmen interested more in securing their business interests than in the public service). In the last parliament, the number of businessmen-politicians further increased (Transparency International, 2017). Although, this group is usually inactive, they have been mobilized when necessary. For instance, in November 2019, the Georgian parliament (thanks to this group) blocked the country's transition from the current mixed system to a fully proportional electoral system, which had wide support from the opposition, civil society and international actors, and that the Georgian Dream and Ivanishvili personally had promised the public (Antidze, 2019).

\subsection{Weakening Party Landscape and Opposition/Ally Management}

The weakening of the parliament has gone hand in hand with the assault on political parties. Already during the 2016 parliamentary elections, Georgian Dream started

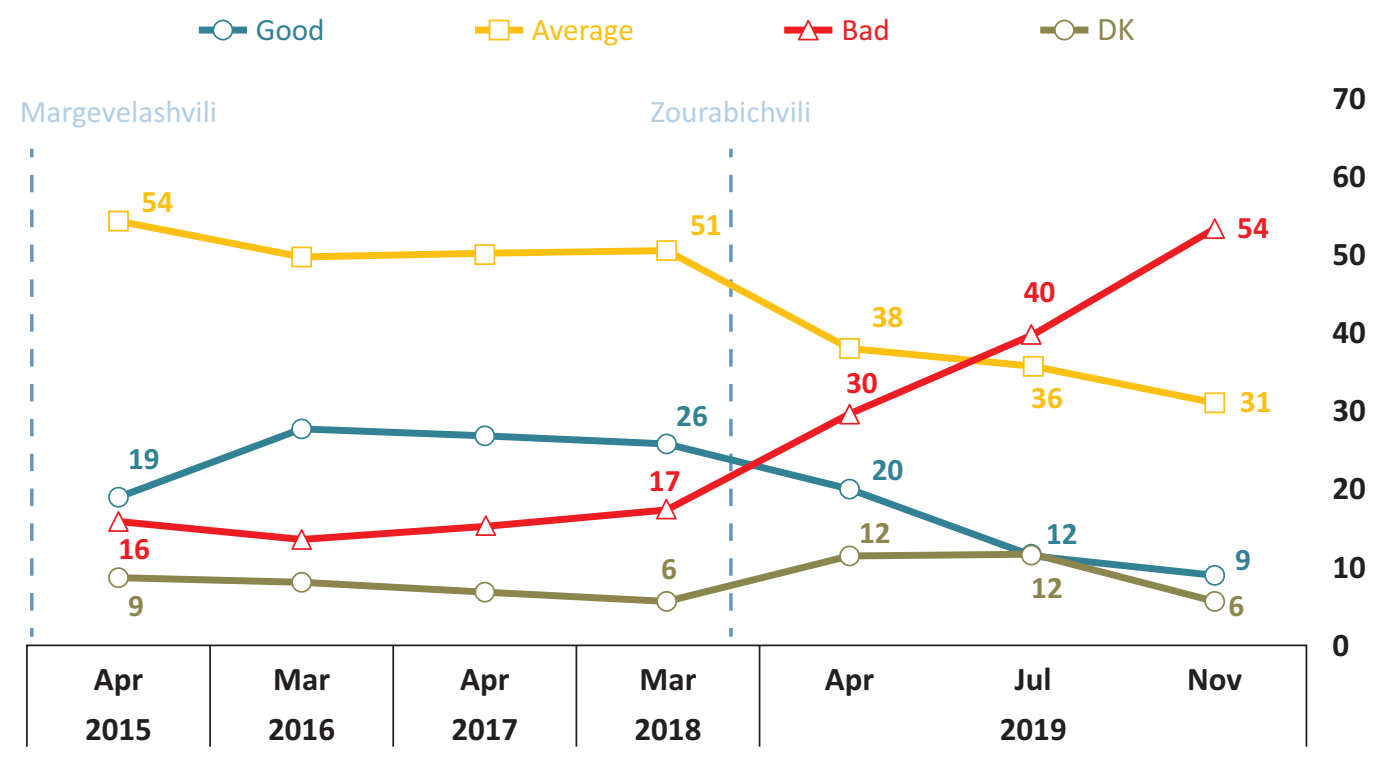

Figure 1. Declining public opinion ratings for the president. Source: National Democratic Institute (2019). 


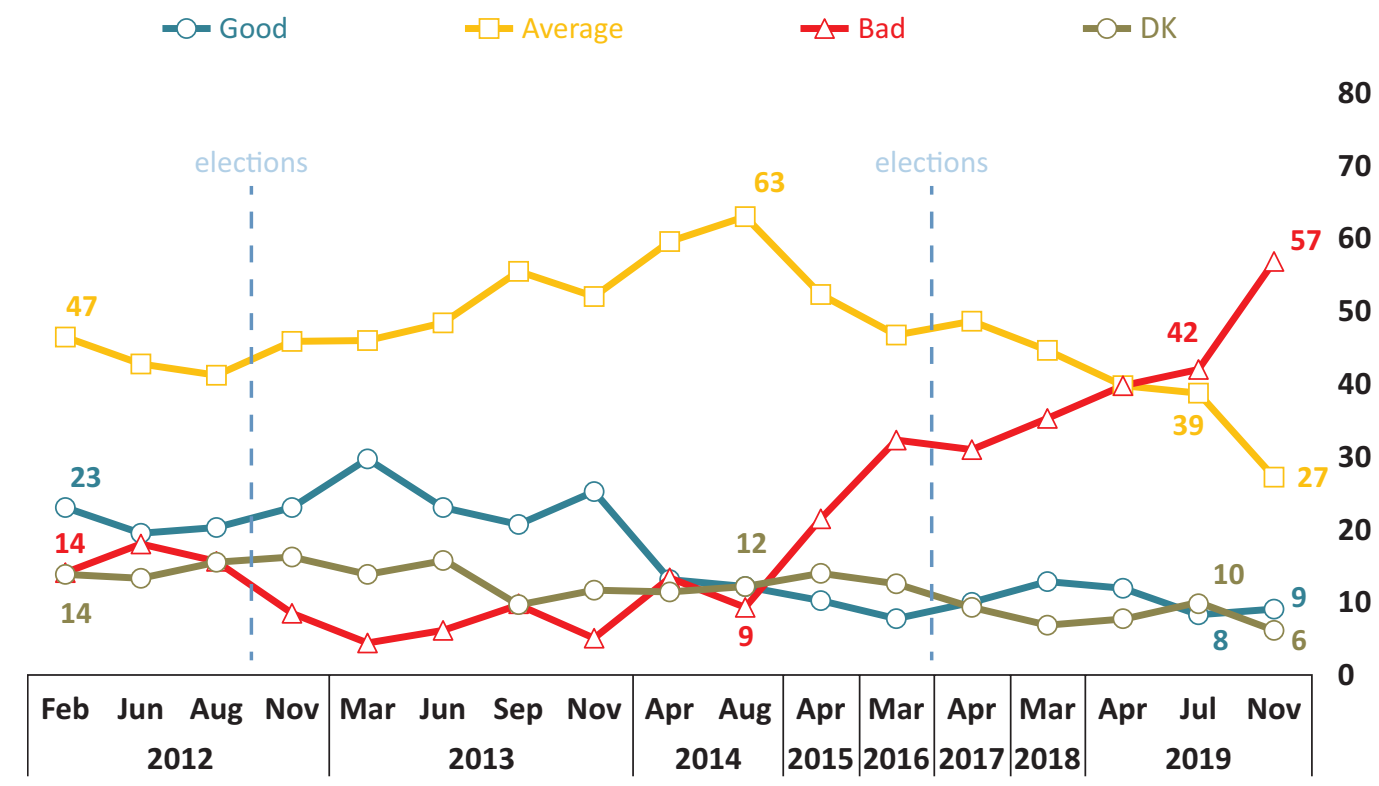

Figure 2. Declining public opinion ratings for the parliament. Source: National Democratic Institute (2019).

attacking its former coalition allies, blaming them for cooperating with the former ruling party, UNM. In this way, Georgian Dream tried to hinder the emergence of alternative players. Its motto 'restoring justice' (arresting officials from the previous administration and the defacto expelling of several others) served to deflect public attention away from the deterioration of democratic institutions and other domestic problems by reminding society that the mistakes of the Georgian Dream are nothing in comparison with crimes of the previous UNM government: "Our opponent is not a political party. Today, unfortunately, we stand opposite the same brutes united for revenge," said Ivanishvili amid the second round of presidential elections 2018 ("Ivanishvili addresses," 2018).

Georgian Dream-affiliated groups have used social media and the judiciary to attack (potential) opposition leaders. One famous case is the story of a cyberattack on the TBC Bank (one of the two leading banks in Georgia), whose leader-Mamuka Khazaradze-had announced his political plans. When the TBC Bank administration determined the location from which the attack was coming, and the media reported about the incident, the authorities did nothing because the company belonged to individuals who were perceived as friends of Ivanishvili (Transparency International, 2019). Later, however, the prosecutor's office launched an investigation into an 11 year-old case involving Khazaradze and his companion, Badri Japaridze (“Ombudsperson," 2020).

Ivanishvili's style of "opposition and ally management' was also on display when the former Tbilisi mayor and one of the leaders of the UNM, Gigi Ugulava, was arrested in 2014 on charges of misusing public funds for party purposes. In January 2017, the Tbilisi Court of Appeal decreased the prison time and he was released. Not by chance, his release coincided with a dispute between supporters of Saakashvili and his opponents within UNM ("Gigi Ugulava," 2017). Ugulava belonged to the wing of the opponents that split UNM into two parts. Later Ugulava became very critical of Ivanishvili and, in February 2020, Ugulava was arrested again. This time, the Supreme Court changed the ruling of the Court of Appeal and increased his prison term ("Opposition leader," 2020).

Finally, Georgian Dream has also pursued cooptation when necessary. In 2012, right after the election, the process of defecting lawmakers from UNM began. The UNM entered with 65 mandates in the 150-seat parliament and after one year had only 52 seats (Atilgan \& Aprasidze, 2013). Many members of the 2016-2020 parliament within Georgian Dream ranks were formerly associated with UNM.

In general, when it comes to restoring justice, it is clear that cases are pursued selectively to intimidate specific individuals and create negative publicity against them, using the technocracy of the judiciary to blackmail and control current and potential adversaries.

\subsection{Balancing and Crisis Management}

Since 2012, Ivanishvili and Georgian Dream have faced several challenges and even crises. The reactions in these critical moments can shed further light on how technocratic populists govern under duress. Crises sometimes bring technocratic populism to the fore, as when the leader engages directly with the public, appealing to his personal ability to solve predicaments.

Technocratic populists try to avoid organized protests and often follow ideology-free flipping and zigzagging. In 2014, despite criticism from nationalist forces close to the influential Georgian Orthodox Church, the Georgian Dream dominated parliament adopted an anti- 
discrimination law, which was a requirement to get the visa-free regime approved by the EU. At the same time, however, Georgian Dream specified (in the constitution) that marriage is a union of a woman and a man to please the forces propagating the idea that the West would force same-sex-marriage onto Georgia (Legislative Herald of Georgia, 2018, Art. 30). In a similar balancing act, Georgian Dream introduced universal health care in 2013 to fulfill one of his electoral promises, but when public expenses skyrocketed from US\$100 million in 2014 to US\$300 million in 2017, the government reverted back to a non-universal system (Absandze, 2018).

During the presidential elections in 2018, when the Georgian Dream candidate Salome Zurabishvili failed to win in the first round, and faced the UNM candidate in the second round, Ivanishvili himself became involved in the campaign. He addressed the population with an open letter, recalling UNM's crimes, while at the same time apologizing for not having fulfilled the promises he made before: "In one year's time, I pledge to correct every mistake in governance and to use all my resources to ensure the irreversibility of the country's development"("Ivanishvili addresses," 2018). In parallel, Ivanishvili's own Qartu foundation announced an initiative to buy the so called 'bad debts' of citizens owed to banks and other lenders, worth GEL1.5 billion in total, which would concern almost 600,000 individuals ("Government announces," 2018), equaling 17 percent of all eligible voters.

'Gavrilov's Night,' in June 2019, represents another critical moment in which technocratic populist rule was on display. As part of a forum of the Interparliamentary Assembly on Orthodoxy held in the building of parliament of Georgia, Sergey Gavrilov-a Russian MPopened the forum from the chair of the speaker. Observing a Member of Parliament of Russia, which is officially regarded as an occupant in Georgia, sitting in the chair of the speaker, caused an immediate protest among the population. Thousands of people spontaneously gathered in front of the parliament building and some protesters tried to get into the parliament. The police used force, injuring more than 200 people, including police officers ("240 injured," 2019). Protests continued despite the violent collapse of the demonstration. The government acted swiftly-the speaker of parliament resigned, and Ivanishvili promised to change the electoral system to a proportional system in 2020, instead of 2024 when it had been previously planned to transition. This was the fundamental demand of the opposition and civil society, and it deescalated the situation. Later, however, when the protest wave dwindled, Ivanishvili and the Georgian Dream failed to deliver on their promise, and blamed the parliament for blocking it (Antidze, 2019). Only under international pressure was the new deal reached to change the electoral legislation in time for the 2020 elections.

In sum, technocratic populism in a hybrid regime context focuses on undermining accountability and dele- gitimizing democratic, representative and intermediary institutions, which could challenge the personalistic legitimacy of the populist leader if they actually carried out their watch-dog functions effectively. Technocratic populists seek to keep the opposition fragmented and discredited, for this enables the effective application of containment-cooptation strategies. Ideology-free programs and initiatives, which often contradict one another, are proposed to win popular support and to selectively buy-off voters but are withdrawn later if and when they prove too costly and/or unnecessary. Ideological flexibility allows populists to be responsive to the immediate needs of pockets of voters and to boost their popularity ratings. Most importantly, when a crisis erupts, the leader is ready to intervene and use his external expertise to fix the situation personally.

\section{Conclusions: Technocratic Populism in Transitioning Countries}

Like Berlusconi and Babiš, Ivanishvili came into politics from the outside (as a businessman), and believed unequivocally that he could transplant the business model he had learned (in the early days of Russian capitalism) to the political realm. His experience, as it turns out, was from operating a business in the shadow of a state that had been effectively captured and was largely beholden to private interests through a parallel system of informal rule bypassing government processes.

Within a short period of time, Ivanishvili implemented a similar system in Georgia by recruiting government personnel based on personal loyalty and installing himself as the key stakeholder of the firm. Democratic institutions (parliament, presidency, political parties, civil society) that possess their own legitimacy and therefore represent a challenge to the leader are purposefully targeted and undermined. Policies are based on the promises of the leader, who presents himself as the only person in the country capable of solving its pressing problems. There is no political ideology or principle-it is just the perception that things are getting done.

In functioning democracies, if a state is captured by business, it raises concerns because it undermines liberal principles and accountability, strengthens various populist movements, and can contribute to democratic backsliding. In hybrid regimes, however, it is much worse, since it forms a new obstacle to democratization and provides incentives for stakeholders to maintain the partial equilibrium of 'façade democracies' (Carothers, 2002). In other words, the 'state as a firm' in hybrid regimes looks less like corporate capitalism and more like 'illiberal oligarchy' ("Illiberal oligarchy," 2019), where both the liberal and majoritarian foundations of democracy are renounced in favor of a corporatist and patrimonial form of governance. Technocratic populism reduces the state into a start-up firm with a small number of stakeholders and a disengaged public sphere. In a weakly institutionalized environment, this bodes ill in 
a world where liberal democracy seems almost everywhere under attack.

\section{Acknowledgments}

An earlier version of this article was presented at the International Workshop: Anti-Elitism: Varieties of Technocratic Populism around the World, at the University of Jena, Germany, in February 2020. We are thankful to the Academic Editors Petra Guasti and Lenka Buštíková for excellent guidance and support throughout, and to three anonymous reviewers for their valuable comments and suggestions.

\section{Conflict of Interests}

The authors declare no conflict of interests.

\section{References}

240 injured during Tbilisi rally, including 80 law enforcers. (2019, June 21). Agenda.ge. Retrieved from https:// agenda.ge/en/news/2019/1642

Absandze, T. (2018, February 6). Sakoveltao jandatsva ar aris sakovaltao [The Universal Healthcare is not Universal]. Forbes Georgia. Retrieved from https://forbes.ge/news/3403/sayovelTao-jandacvaar-aris-sayovelTao

Antidze, M. (2019, November 14). Georgia's parliament fails to pass electoral changes, triggering protest. Reuters. Retrieved from https://www.reuters.com/ article/us-georgia-politics/georgias-parliamentfails-to-pass-electoral-changes-triggering-protestidUSKBN1XO1QA

Atilgan, C., \& Aprasidze, D. (2013). End to an era: Transfer of power in Georgia. KAS International Reports, 4(12), 69-88.

Bader, M. (2009). Understanding party politics in the former Soviet Union: Authoritarianism, volatility, and incentive structures. Demokratizatsiya, 17(2), 100-120.

Bartha, A., Boda, Z., \& Szikra, D. (2020). When populist leaders govern: Conceptualising populists in policy making. Politics and Governance, 8(3), 71-81.

Berglund, C. (2014). Georgia between dominant-power politics, feckless pluralism, and democracy. Demokratizatsiya, 22(4), 445-470.

Bickerton, C., \& Accetti, C. I. (2017). Populism and technocracy: Opposites or complements? Critical Review of International Social and Political Philosophy, 20(2), 186-206.

Bloomberg. (2020). Blumberg billionaires index. Bloomberg. Retrieved from https://www.bloomberg. com/billionaires/profiles/bidzina-ivanishvili

Braguinsky, S. (2009). Postcopmmunist oligarchs in Russia: Quantitative analysis. Journal of Law and Economics, 52(2), 307-349.

Buckley, N. (2012, October 25). Georgia's billionaire premier: Can Bidzina Ivanishvili, once a reclusive tycoon and now the country's incoming prime minister, bring real democracy? Financial Times. Retrieved from https://www.ft.com/content/57de74bc-1e3711e2-8e1d-00144feabdc0

Buštíková, L., \& Babos, P. (2020). Best in Covid: Populists in the time of pandemic. Politics and Governance, 8(4), 496-508.

Buštíková, L., \& Guasti, P. (2019). The state as a firm: Understanding the autocratic roots of technocratic populism. East European Politics and Societies, 33(2), 302-330.

Caiani, M., \& Graziano, P. (2019). Understanding varieties of populism in times of crises. West European Politics, 42(6), 1141-1158.

Canovan, M. (1999). Trust the people! Populism and the two faces of democracy. Political Studies, 47(1), 2-16.

Caramani, D. (2017). Will vs. reason: The populist and technocratic forms of political representation and their critique to party government. American Political Science Review, 111(1), 54-67.

Carothers, T. (2002). The end of the transitional paradigm. Journal of Democracy, 13(1), 5-21.

De la Torre, C. (2013). Latin America's authoritarian drift: Technocratic populism in Ecuador. Journal of Democracy, 24(3), 33-46.

Gente, R. (2013). Bidzina Ivanishvili, a man who plays according to Russian rules? Caucasus Survey, 1(1), 117-126.

Georgian Dream. (2020). About us. Georgian Dream Party Website. Retrieved from http://gd.ge/About-Us

Gigi Ugulava released from prison. (2017, January 6). Civil Georgia. Retrieved from https://old.civil.ge/eng/ article.php?id=29748

Government announces deal to write off bad debts. (2018, November 11). Civil Georgia. Retrieved from https://civil.ge/archives/266476

Grzymala-Busse, A. (2019). How populists rule: The consequences for democratic governance. Polity, 51(4), 707-717.

Guasti, P. (2020). Populism in power and democracy: Democratic decay and resilience in the Czech Republic (2013-2020). Politics and Governance, 8(4), 473-484.

Guasti, P., \& Buštíková, L. (2020). A marriage of convenience: Responsive populists and responsible experts. Politics and Governance, 8(4), 468-472.

Guriev, S., \& Rachinsky, A. (2005). The role of oligarchs in Russian capitalism. Journal of Economic Perspectives, 19(1), 131-150.

Hale, H. (2010). Why not parties in Russia? Democracy, federalism, and the state. Cambridge: Cambridge University Press.

Hammarberg, T. (2013, September 13). Georgia in transition: Report on the human rights dimension: Background, steps taken and remaining challenges (Special Report). Tbilisi: Government of Georgia. Retrieved from http://gov.ge/files/38298_38298_ 
595238_georgia_in_transition-hammarberg1.pdf

Hellman, J. (1998). Winners take all: The politics of partial reform in Postcommunist transitions. World Politics, 50(2), 203-234.

Highlights: President Zurabishvili's televised interview. (2019, March 20). Civil Georgia. Retrieved from https://civil.ge/archives/279977

Illiberal oligarchy lurks behind Georgia's democratic façade. (2019, November 21). Civil Georgia. Retrieved from https://civil.ge/archives/328613

Ivanishvili, B. (2011a, October 7). Written statement. Civil Georgia. Retrieved from https://old.civil.ge/eng/ article.php?id=24006

Ivanishvili, B. (2011b, October 12). Open letter to Georgian government, politicians, political parties, media outlets and Georgian citizens. Civil Georgia. Retrieved from https://old.civil.ge/eng/article.php? id $=24023$

Ivanishvili, B. (2013, November 13). I quit politics, but remain an active citizen. Civil Georgia. Retrieved from https://old.civil.ge/eng/article.php?id=26721

Ivanishvili addresses the Nation. (2018, November 5). Civil Georgia. Retrieved from https://civil.ge/archives/ 263703

Lanskoy, M., \& Areshidze, G. (2008). Georgia's year of turmoil. Journal of Democracy, 19(4), 154-168.

Legislative Herald of Georgia. (2018). Constitution of Georgia. Legislative Herald of Georgia. Retrieved from https://matsne.gov.ge/en/document/view/ 30346? publication $=35$

Lomsadze, G. (2018, July 27), Billionaire's big talk on his plans for Georgia. Eurasianet. Retrieved from https://eurasianet.org/billionaires-big-talk-onhis-big-plans-for-georgia

March, L. (2017). Populism in the Post-Soviet states. In C. R. Kaltwasser, P. Taggart, P. Ochoa Espejo, \& P. Ostiguy (Eds.), The Oxford handbook of populism (pp. 214-231). Oxford: Oxford University Press.

Migdal, J. S. (1989). Strong societies and weak states: State-society relations and state capabilities in the third world. Princeton, NJ: Princeton University Press.

Mudde, C. (2004). The populist zeitgeist. Government and Opposition, 39(4), 541-563.

Mudde, C., \& Kaltwasser, C. R. (Eds.). (2012). Populism in Europe and the Americas: Threat or corrective for democracy? New York, NY: Cambridge University Press.

National Democratic Institute. (2019). Public attitudes in Georgia. Washington, DC: National Democratic Institute. Retrieved from https://www.ndi.org/sites/
default/files/NDI\%20Georgia_December\%202019_ Public\%20Presentation_ENG_VF.pdf

Ombudsperson: Khazaradze-Japaridze case materials 'do not contain' money laundering elements. (2020, January 15). Civil Georgia. Retrieved from https:// civil.ge/archives/334675

Opposition leader Ugulava sentenced to 3 years in prison. (2020, February 10). Agenda.ge. Retrieved from https://agenda.ge/en/news/2020/422

Pappas, T. (2019). Populists in power. Journal of Democracy, 30(2), 70-84.

PM Ivanishvili demotes Alasania. (2012, January 13). Civil Georgia. Retrieved from https://civil.ge/archives/ 122550

Siroky, D. S., \& Aprasidze, D. (2011). Guns, roses and democratization: Huntington's secret admirer in the Caucasus. Democratization, 18(6), 1227-1245.

Stanley, B. (2008). The thin ideology of populism. Journal of Political Ideologies, 13(1), 95-110.

Stevenson, W. (2010). The good oligarch. Prospect Magazine. Retrieved from https://www. prospectmagazine. co.uk/magazine/bidzina-ivanishvili-georgiabillionaire-philanthropist

The most mysterious Russian billionaire Boris Ivanishvili broke a vow of silence. (2005, April 7). News.ru. Retrieved from https://www.newsru.com/finance/ 07apr2005/ivanishvili.html

Transparency International. (2017). Business connections of MPs: Incompatible activities and undeclared assets. Transparency International. Retrieved from https://transparency.ge/en/post/businessconnections-mps-incompatible-activities-andundeclared-assets

Transparency International. (2019). Investigation's silence about cyberattack on TBC Bank raises questions. Transparency International. Retrieved from https://www.transparency.ge/en/post/ investigations-silence-about-cyberattack-tbc-bankraises-questions

Walker, C. (2011). The authoritarian dead end: The Arab Spring's implications for the former Soviet Union. Washington, DC: Freedom House. Retrieved from https://freedomhouse.org/sites/default/files/ inline_images/NIT-2011-Release_Booklet.pdf

Weyland, K. (2020). Populism's threat to democracy: Comparative lessons for the United States. Perspectives on Politics, 18(2), 389-406.

Wheatley, J. (2005). Georgia from national awakening to Rose Revolution: Delayed transition in the former Soviet Union. London: Routledge.

\section{About the Authors}

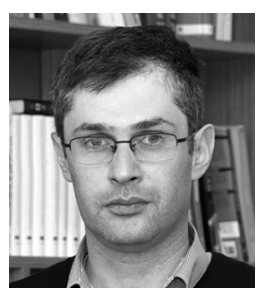

David Aprasidze is a Professor of Political Science at Ilia State University, Tbilisi, Georgia. He received his PhD from Hamburg University, Germany, and was a Fulbright scholar at Duke University, North Carolina, US. At various times, he has worked for public agencies and international NGOs operating in Georgia and has expertise in higher education management. His research interests include on political institutions and democratization. 
David S. Siroky is an Associate Professor of Political Science in the School of Politics and Global Studies at Arizona State University, where he is a Core Faculty Member of the Center for Social Dynamics and Complexity and the working group on Nationalist and Ethno-Religious Dynamics, as well as a Faculty Affiliate of the Center for the Study of Religion and Conflict, the Center for Jewish Studies, the Melikian Center for Russian, Eurasian and East European Studies, and the Center on the Future of War. 